\title{
Effect of Personal and Occupational Characteristics on Attitudes to an Obligatory Retirement Age-A Content Analysis Investigation
}

\author{
Eyal Eckhaus ${ }^{1} \&$ Nitza Davidovitch ${ }^{2}$ \\ ${ }^{1}$ Department of Business and Economics, Ariel University, Israel \\ ${ }^{2}$ Head of Academic Quality and Assessment, Head of Teacher Training Program, Ariel University, Israel \\ Correspondence: Eyal Eckhaus, Department of Business and Economics, Ariel University, Israel. E-mail: \\ eyale@ariel.ac.il
}

Received: October 2, 2019

Accepted: November 1, 2019 Online Published: November 17, 2019

doi:10.5539/jel.v8n6p169

URL: https://doi.org/10.5539/jel.v8n6p169

\begin{abstract}
This study is a pioneer study examining the effects of personal and occupational background variables on the attitude of faculty members to an obligatory retirement age in academia. Previous studies on performance measures of academic faculty in research, teaching, academic administration, and contribution to the community, testified to associations between faculty member achievements and their personal characteristics (gender, age) as well as features related to their academic field of occupation (faculty, academic rank, tenure). Hence, these quality measures of academic faculty have meaning for and influence on research, even after the customary retirement age.

Obligatory retirement age is a well-known issue and it is arousing much interest in general, and in academia in particular. Academic work includes activity focused on research, teaching, advisory work, participation in academic committees and conferences - namely, activities that require human thinking. This leads to the question of whether and to what degree personal and occupational characteristics are associated with the attitude of faculty members to retirement age.

One hundred and eight questionnaires administered to senior faculty were collected in a case study of a single university. Qualitative and statistical research tools were employed, with the aim of creating a model that expresses the association between faculty members' personal and occupational characteristics and their attitude to retirement age in academia. The research findings show that the background variables affecting the attitude of faculty members to retirement are age and tenure-faculty members' age and status as tenured faculty determine their objection to the obligatory retirement age.
\end{abstract}

Keywords: retirement age, employment, academia, work capability, academic ranks

\section{Introduction}

Previous studies on performance measures of academic faculty in research, teaching, academic administration, and contribution to the community (Davidovitch \& Sinuani-Stern, 2014; Davidovitch, Soen, \& Sinuani-Stern, 2011) have testified to associations between the achievements of faculty members, their personal characteristics (gender, age), and features related to their academic field (faculty, academic rank, tenure).

Evaluating the activity of faculty members and performance-based rewards have become important topics in the last four decades (Wadsworth, 1994; Gillespie, Hilsen, \& Wadsworth, 2002). Faculty members in academic institutions perform a wide range of activities that include teaching, research, research publications, presenting at conferences, submitting research grants, academic administration, community service, and others (Kreber, 2001). Hence, the current researchers' point of departure is that these quality measures of academic faculty have meaning for and influence on the different disciplines even after the customary retirement age (Achdut \& Litwin, 2008).

Using a case study, we examine the effect of personal and occupational background variables on the attitude of faculty members to an obligatory retirement age in academia, assuming that changes are occurring in life expectancy and in quality of life in general. Building on the assumption that the inclusion of experienced faculty members is essential and crucial and that research is an important tool outlining the future course of academic institutions - the question explored was whether the continued employment of retired faculty enriches and 
contributes to the academic field of activity or not. The researchers' point of departure is that performance quality measures of academic faculty have meaning for and influence on research, which is the dominant criterion for advancement within academic systems, and therefore the researchers estimate that the crucial weight of research within the activity of academic faculty members has meaning and influence even after the official retirement age, in how knowledge is formed and conveyed and as an influential factor that shapes role models for future generations of researchers.

\subsection{On Retirement Age in Academia}

Until 2004 Israel had no law regulating the issue of retirement age. In most cases, retirement age was determined in labor agreements in the public sector (Hantman, 2012). On April 1, 2004, the Retirement Age Law was enacted in Israel. The Retirement Age Law (Klinov, 2007) gradually raises the retirement age for women (at present 62) and men (at present 67). Moreover, the retirement age in sectors such as nursery school teachers, police officers, and professional soldiers, has been raised in stages. Retirement arrangements for various sectors are regulated by law, through laws such as the Civil Service Law (Retirement) and the Permanent Service in the Israel Defense Forces Law (Retirement). In addition, the Retirement Age Law instituted other laws determining rights and obligations deriving from the retirement age (such as the Senior Citizens Law, the Families of Fallen Soldiers Law (Pensions and Rehabilitation), and the Income Tax Order) and adapted them to the new instructions (Klinov, 2007). Over the years, the law was updated:

- Amendment no. 3 (December 26, 2011) deferred to 2017 the gradual raise of women's retirement age from 62 to 64 . Towards 2017 a committee will be established to reexamine this issue. Furthermore, the National Insurance Law was instituted, reflecting the retirement age for women as following from the amendment to the Retirement Age Law.

- Amendment no. 6 (July 24, 2017) determined that the Minister of Finance will submit his recommendations for approval of the Finance Committee, taking into account the recommendations of the public committee established for this topic (as of May 2019 no decisions have been reached as to the further raising of women's retirement age, which has remained at 62).

On August 26, 2017, a joint bill was submitted by the coalition and opposition: workers would not be obliged to retire at 67 as customary until then (Kimhi \& Shraberman, 2013). The reason for this is that some workers are at their best at this age.

A bill in this spirit was submitted to the Knesset jointly by the chairperson of the coalition and the head of the opposition factions. The bill proposes that the definition of the legal obligatory retirement age be changed to form a flexible retirement mechanism inspired by global legislative trends. The proposed mechanism expands workers' capacity to determine their age of retirement. According to the proposal, employers can oblige workers to retire when reaching 67 only following a personal occupational medical examination or another examination customary in the workplace as selected by the workers, which determines that they are incapable of performing their job. Moreover, employers must make an effort to find such workers suitable alternative roles.

At present, as of 2019, the obligatory retirement age is 67 for both men and women, where the law allows women to retire at 62 and to receive a pension. Namely, workers have no choice and employers may require them to retire when reaching 67 (Paltiel, Spolker, Konilko, \& Maldondo, 2011; Brodsky, Schneor, \& Be'er, 2015). The explanation to the bill notes that many workers aged 67 are at the height of their career and are attaining far-reaching professional achievements. They and their employers benefit from the knowledge, experience, and expertise accumulated over the years. Hence, everybody loses from obliging workers to stop working at this stage (Leitner \& Leitner, 2014).

The bill mentions a study by the Jerusalem Institute for Policy Research (Golan \& Harel Harari, 2010), whereby employment of older people has significant financial potential and by not employing them the state incurs an annual financial loss of NIS 6.4 billion. The bill also mentions studies whereby a sharp transition from employment to lack of employment may generate mental decline and a sense of uselessness among retirees. It is also proposed in the existing research that employers shall be entitled to stop retirement fund payments, while maintaining the accumulated rights of workers who remain after the age of 67 . The purpose is to give employers an incentive to employ workers after retirement age and to reduce their expenses (Brodsky, Schneor, \& Be'er, 2015).

The bill aims to advocate both for those who are at the height of their productivity at age 67 as well as for the state coffers that will have to pay out less pensions for less time, without harming those who are not prepared to continue working past this age. Life expectancy and the structure of the economy are changing. It is time to 
adjust the retirement age accordingly and to cancel the mandatory retirement age.

In 2019 the Ministry of Finance submitted a proposal whereby raising the retirement age for women would occur gradually over 11 years (Avisar, 2019). According to the Ministry of Finance's legal memorandum, this is a gradual procedure aimed at raising the retirement age from 62 to 65 , where women now 61 will be the first to benefit from it; as of January 2037, a mechanism will be operated to raise the retirement age in accordance with changes in life expectancy, such that it will not exceed that of men. The draft postponed cuts to existing pensions but was only slated to be submitted for approval after the 2019 elections; accordingly, the Histadrut Workers' Union cancelled the general nationwide labor dispute planned (Millman, 2019).

The Ministry of Finance issued a legal memorandum for raising the retirement age for women, now at 62 . According to the proposal, this is a procedure that will take effect gradually over 11 years, beginning from this coming April. In the first three years the retirement age will be raised at a rate of 4 months a year, and subsequently - at a rate of 3 months a year. Then the retirement age will be linked to the life expectancy (estimated to rise at a rate of one month a year), where the retirement age for women will not exceed that of men.

The first stroke, in which the retirement age will be raised 4 months each year, will apply to those born from June 1958 to May 1959 (i.e., aged 61 today); and the first stroke for raising the retirement age from 63 to 65 at a rate of 3 months a year will apply to those born from June 1961 to May 1962 (Avisar, 2019). In the second stage, from January 2037 an automatic mechanism is proposed for raising the retirement age for women according to changes in life expectancy such that, as stated, their retirement age will not exceed that of men. This will take place as follows: Each rise of one year in life expectancy will raise the retirement age by eight months, with the aim of maintaining the same ratio between years of work and years of retirement.

According to the Ministry of Finance, raising women's retirement age to 65 will improve the financial state of the National Insurance Institute by billions of shekels, subject to actual changes in life expectancy. This means deferring the cut that was to have been applied to existing pensions from July this year to April 2020. Accordingly, the Histadrut Worker's Union announced that the general nationwide labor dispute was cancelled (Ministry of Finance, 2015). The Ministry of Finance reported that the Ministry of Justice is in favor of this course. Although the legal memorandum for raising the retirement age has already been issued, it will probably be submitted for the government's approval only after the 2019 elections, once the new government is established.

The draft is based on recommendations by the public committee established by the former Director of Budgets, Amir Levy, together with the National Insurance Institute and other representatives, and which submitted its recommendations in 2016. It determined that the retirement age for women should be raised to age 65 over 12 years, at a rate of 3 months a year. Since this is not happening, the Ministry of Finance is now seeking to expedite the rate, at least at the beginning, in order to prevent cuts to the veteran pension funds following the deficit resulting from not raising women's retirement age. This is a procedure that the Ministry of Finance has been trying to push since 2003, however as of now the Ministers of Finance have been unsuccessful (and made no real effort).

Personnel in the National Insurance Institute informed (Gorali, 2014) that "as early as the National Insurance report for 2013 we proposed a fair outline for raising the retirement age. We took into account the sensitivities involved in raising the retirement age, a step required by the significant rise in life expectancy. The National Insurance Research Department presented the Ministry of Social Affairs with a reasonable social outline, whereby the years added to the current retirement age would take into account the worker's age and a 62 -year-old woman would be able to retire today while an 18 -year-old woman will retire at age 67 ". They also added that "The National Insurance [Institute] suggested that the retirement age not be raised automatically for women who are currently close to retirement, rather only for the young generation who have more years to accumulate rights. In addition, as a society we must be considerate of women engaged in draining professions. According to the policy of the Minister of Social Affairs we will be full partners in providing a suitable social response for solving this issue, and we recommend consulting the data and knowledge that we have acquired".

Attorney (accountant) Amir Gabay claims that the attitude to retirement age must change. His main arguments are as follows: Retiring from work is a meaningful event in one's life, and Gabay says that it is perfectly clear that the issue of retirement age cannot be discussed without referring to occupational considerations and to health implications. A narrow discussion that focuses only on the direct financial aspect is fundamentally wrong and doomed to failure. 


\subsection{Retirement Age and Women}

Retirement age is not a "problem" that pertains only to women, it is a problem that is relevant for all of us, both men and women. Discussing the policy regarding retirement age while distinguishing between men and women is old politics. The struggles of a female production worker during her lifetime are no different than those of a male production worker. The circumstances of a female professor at a university are no different than those of a male professor. Whether the retirement age should be raised or lowered, it must be the same for both men and women. As a rule, real and true equality between the sexes will only be achieved when no distinction is made between them.

\subsection{The Spirit of the Times and Progress}

We would not want to force hi-tech companies by legal means to employ workers who last saw a school 30 years ago or more, nor would we want to be served at a government office by a worn-out official who has not been allowed out of his chair for 30 or 40 years. Moreover, we would not want to block young workers from advancing and to create a bottleneck at the entrance to the employment cycle (Weissberg, 2012).

Most people want to work after retirement age (Richert-Kaźmierska, 2014). When academic faculty members reach retirement age they may have a higher rank, however, since academic rank does not imply work output (Mayer, Lenherr, Hanson, Jessop, \& Lowrance, 2017), motivation to continue working is not necessarily affected by rank, but mainly by age. Any recommended solution that disregards progress, the growing population, financial considerations and considerations of efficacy, as well as both the needs of the old and the needs of the young - is not the correct solution. We would do better, at present and in the future, to reach our hand into our pocket. We would do well if the young would fund the old, while not only realizing the great precious potential of older people but rather utilizing it for the benefit of society at large by using alternative means.

\subsection{Fairness Rather than Equality}

Richert-Kaźmierska (2014) relates to veteran immigrants who are very well educated. They immigrated to Israel at a relatively advanced age, after acquiring knowledge and an education abroad, but they arrived with no property. Here, in Israel, they work hard at jobs that are highly remunerated (Tur-Sinai, 2016).

When these workers, veteran immigrants, retire from work, they must cope with a drastic drop in their monthly income. Some are financially ruined and become destitute. Their period of work in Israel is relatively short, they spend relatively few years depositing in pension funds, their rights are more limited, and some even continue to pay a mortgage while in retirement.

Here it must be stressed that when they are able and capable they continue to work. Even after reaching retirement age, even in alternative jobs. This is an example of a population that deserves distinct attention and a different legal solution. We must find the proper way to allow them continue to work. The Retirement Age Law must be based on foundations of fairness rather than on foundations of equality. As stated, in his opinion (Tur-Sinai, 2016) gender is not a basis for distinction, but there is no lack of parameters that we must define and follow (Tur-Sinai, 2016).

\subsection{Returning the "Aunties" to the Army}

Occupation equals health. Occupied people make less visits to the doctor. Occupied people spend less money. An occupied person can make do with a smaller income. Many people hold on to their jobs only because they are anxious about staying at home alone unoccupied and not because they do not have enough money to retire. Widowers, divorced, and singles, continue to work because they seek company, not money.

Tur-Sinai (2016) says that we do not want our parents to die mentally or physically on an assembly line but still want them to be occupied, because occupation is health and occupied people spend less money. And he stresses that many others need more income and financial support even before reaching the currently legal retirement age, because no one wants to continue employing them (Tur-Sinai, 2016).

Assuming that we do not wish to bar young workers from advancing and to form a bottleneck at the entrance to the employment cycle, we should not disregard progress, the population growth, financial considerations, and efficacy considerations, and it would be better for all of us if we would reach into our pockets and if the young would finance the old, while at the same time not only realizing the great precious potential of older people but rather utilizing it for the benefit of society at large by using alternative means.

\subsection{Occupation and the Good of Society}

Constantly raising the retirement age by law and thus "compelling" some employers to continue employing older 
workers may be a solution that does not fit the real financial circumstances and other considerations described above (Cohen, 2019). Suggestions such as lengthening the period of paid unemployment for older people only mean deferring the problem to a later stage. Cohen (2019) recommends, for instance, that decision makers check how many of those who retire relatively early, those who choose to establish their own business when retiring, truly manage to "repay" all the retirement compensation they invested in their business.

Endless tax raises that the workers do not enjoy, even indirectly, are not the solution either. If the state through old age pensions, meaning us the taxpayers, would fund the older population even when younger than legally mandated at present, while creating settings in which we can provide these people with occupation, give their lives content and meaning at an older age as well, realize and utilize the considerable knowledge and experience they accumulated during their work life for the purpose of realizing social causes - we would all benefit, the old and the young, the current generation and the future generation (Cohen, 2019). There is no lack of social and business projects that would benefit us all, in both the short and long term. The great potential that exists in older people who have precious life experience and knowledge and are capable of contributing to us all for many years to come, can be realized (Milgram \& Davidovitch, 2010).

These processes can be managed lucratively. All the ideas proposed here can contribute financially both to the individual and to society as a whole. All that is necessary is vision and an open mind. The issue of retirement age should be treated from a wide perspective rather than a narrow one. There are alternative ways, better than those currently proposed, to handle the issue of retirement age that is troubling us all, both as individuals and as a society.

We will gain happier and healthier parents capable of subsisting honorably. In time and if the processes are properly managed, we will be able to both pay less taxes and to pay them more than what they are currently receiving from the government. We will be able to support weaker populations and, in the long term, we will gain a younger generation that will be even better than the current one.

\subsection{Research Rationale}

In light of the research literature and the bills submitted in this area, the current research hypotheses are:

1) Tenure and Age negatively affect the attitude to an obligatory retirement age.

2) There is no difference among the ranks in their attitude to an obligatory retirement age.

3) Gender does not affect the attitude to an obligatory retirement age.

\section{Method}

In order to construct the model, each of the hypotheses is detailed with sub-hypotheses as follows, inline with the relationships in the model, as follows.

\section{1) Tenure and Age negatively affect the attitude to an obligatory retirement age}

H1. Tenure negatively affects TXT1

H2. Age negatively affect TXT1

H3. Tenure negatively affects TXT2

H4. Age negatively affect TXT2

\section{2) There is no difference among the ranks in their attitude to an obligatory retirement age}

H5a. Senior teacher rank positively affects TXT1

H5b. lecturer rank positively affects TXT1

H5c. Senior lecturer rank positively affects TXT1

H5d. Associate professor rank positively affects TXT1

H5e. Full professor rank positively affects TXT1

H5f. Professor emeritus rank positively affects TXT1

H5g. Senior teacher rank positively affects TXT1

H5h. Lecturer rank positively affects TXT1

H5i. Senior lecturer rank positively affects TXT1

H5j. Associate professor rank positively affects TXT1 
H5k. Full professor rank positively affects TXT1

H51. Professor emeritus rank positively affects TXT1

H6a. Senior teacher rank positively affects TXT2

H6b. Lecturer rank positively affects TXT2

H6c. Senior lecturer rank positively affects TXT2

H6d. Associate professor rank positively affects TXT2

H6e. Full professor rank positively affects TXT2

H6f. Professor emeritus rank positively affects TXT2

H6g. Senior teacher rank positively affects TXT2

H6h. Lecturer rank positively affects TXT2

H6i. Senior lecturer rank positively affects TXT2

H6j. Associate professor rank positively affects TXT2

H6k. Full professor rank positively affects TXT2

H61. Professor emeritus rank positively affects TXT2

\section{3) Gender does not affect the attitude to an obligatory retirement age.}

H7a. There is no effect of Gender on TXT1

H7b. There is no effect of Gender on TXT2

\subsection{Initial Sample and Tool}

Two open-ended questions were asked in a questionnaire that also inquired about age, gender, tenure, and academic rank, as follows: senior teacher (STE), lecturer (LEC), senior lecturer (SLEC), associate professor (APROF), full professor (FPROF), and professor emeritus (EME). In the open questions, respondents were asked for their opinion on limiting employment to retirement age (TXT1), and whether an obligatory retirement age has the advantage of enabling the absorption of new faculty members (TXT2).

Google Docs was used to distribute the questionnaires online to the senior faculty members at Ariel University, Israel, and 108 completed questionnaires were collected. Gender-wise, $47.6 \%$ were females and $52.4 \%$ males. The age range of the respondents was 36-49 (36.6\%), 50-60 (32.3\%), and 61-84 (31.2\%). Academic ranks were in the following range: teacher (3\%), senior teacher $(9 \%)$, lecturer $(23 \%)$, senior lecturer $(32 \%)$, associate professor (18\%), professor ( $8 \%$ ), professor emeritus (2\%), and other unspecified (5\%). Regarding tenure, $46.2 \%$ of the respondents had tenure and $53.8 \%$ did not. The respondents belonged to the following faculties: $50.6 \%$ social sciences, $13.6 \%$ health, $6.2 \%$ natural sciences, $6.2 \%$ architecture, and $23.5 \%$ engineering.

\subsection{Analysis}

The current study is a mixed methods research (Molina-Azorin, 2016), which combines the strengths of the qualitative and empirical methods and facilitates better understanding of the research question (Davidovitch \& Eckhaus, 2019a, 2019b; Eckhaus \& Davidovitch, 2019). In the first step, all the responses to the open questions were manually coded. This manual process is known as text categorization (Narhari \& Shedge, 2017), in which the content is manually overviewed and major themes are identified (Davidovitch \& Eckhaus, 2018; Eckhaus \& Davidovitch, 2018a, 2018b). Specifically, for the purpose of this study positive replies to the first and second questions were tagged. The tagging process was performed by using a binary system (Eckhaus \& Sheaffer, 2018b), i.e., coding 1 when the response was positive and 0 when negative.

In order to test the model's goodness-of-fit, Structural Equation Modeling (SEM) (Eckhaus, 2019a; Eckhaus \& Sheaffer, 2018a), a powerful, multivariate technique (Eckhaus, 2019b), was utilized. The indices used to estimate model fit were CMIN/DF, RMSEA, TLI, CFI. Values of RMSEA $<.06$, CFI and TLI $\geqslant .95$ are indication of good fit (Schreiber, Nora, Stage, Barlow, \& King, 2006). The ratio CMIN/DF should be $<3$ (Stegers-Jager, Cohen-Schotanus, \& Themmen, 2012), however, the stricter approach argues that the ratio CMIN/DF should be $<2$. A correlation was assumed and modeled between Age and Tenure, which is intuitive. A correlation was also modeled between age and the lower three academic ranks, assuming a negative correlation, which is also intuitive. Similarly, between Tenure and the three lowest academic ranks; since teacher and lecturer ranks cannot receive tenure, a negative correlation should be shown; only from senior lecturer rank and above is tenure possible, therefore a positive correlation should be shown. 


\section{Qualitative Results}

\subsection{Examples from the Replies of Respondents Who Objected to the Retirement Age}

To the second question, on whether the retirement age should be limited in order to enable acceptance of new faculty members, a 72-year-old respondent replied "that's what happened to me", stressing the personal aspect of the problem. Other respondents aged 70+ simply answered "No", while others added: "No; as stated, if the faculty member is effective there is no reason to accept someone else instead", "Not at all, retirement age is arbitrary, and each person should be able to choose when to retire."

\subsection{Examples from the Replies of Respondents in Favor of an Obligatory Retirement Age}

To the first question on whether employment should be restricted by setting an obligatory retirement age, eight respondents aged 38 to 46, of whom only two had tenure, answered simply "Yes", without expanding. Others provided more detail in answer to both questions: "Faculty members can't occupy their job forever", "As a rule, the process is desirable in order to refresh the faculty", "Yes. The ranks should be refreshed, giving an opportunity to other people. Otherwise, there is no turnover". "Yes. This creates a power multiplier for the university, as emeriti publish and create research output and so do their new replacements". "When the older staff retire the young can be promoted". "As a rule, the process is desirable in order to refresh the staff". "Yes, young staff should be able to join."

\subsection{At the Same Time, the Contribution of Older Faculty Members Was Recognized}

In answer to the first question on whether employment should be restricted by setting an obligatory retirement age, a 61-year-old respondent said: "No, so long as one is productive from a research perspective, advises graduate students, and is prepared for the challenge of teaching". Another respondent added: "Selectively-let outstanding faculty members continue beyond the [retirement] age". "In our field, particularly in research, the existence of senior faculty members in the system can contribute to younger faculty members". "Retirees can guide research and support young researchers. They can, of course, use the library and all university facilities, and obviously publish".

\section{Empirical Results}

Table 1 presents Spearman's correlations, means, and SD. Figure 1 illustrates the model and the results.

Table 1. Correlation matrix: means and SD

\begin{tabular}{|c|c|c|c|c|c|c|c|c|c|c|c|}
\hline & Age & Tenure & Gender & $T X T 1$ & $T X T 2$ & STE & $L E C$ & SLEC & $A P R O F$ & FPROF & $E M E$ \\
\hline Age & - & & & & & & & & & & \\
\hline Tenure & $.28 * *$ & - & & & & & & & & & \\
\hline Gender & .06 & -.12 & - & & & & & & & & \\
\hline$T X T 1$ & -.19 & -.09 & .15 & - & & & & & & & \\
\hline$T X T 2$ & $-.27 * *$ & -.03 & .02 & $.40 * * *$ & - & & & & & & \\
\hline STE & -.05 & .003 & -.13 & -.10 & -.06 & - & & & & & \\
\hline$L E C$ & $-.35 * * *$ & $-.35 * * *$ & -.04 & .03 & .01 & -.17 & - & & & & \\
\hline SLEC & -.11 & $.37 * * *$ & -.01 & .02 & .02 & $-.22 *$ & $-.38^{* * *}$ & - & & & \\
\hline APROF & $.30 * *$ & .06 & .02 & .04 & .03 & -.15 & $-.26^{*}$ & $-.32^{* * *}$ & - & & \\
\hline FPROF & $.34 * * *$ & .12 & .13 & -.17 & -.09 & -.09 & -.16 & $-.20 *$ & -.14 & - & \\
\hline$E M E$ & $.23^{*}$ & .09 & .13 & -.08 & -.19 & -.05 & -.08 & -.10 & -.07 & -.04 & - \\
\hline Mean & 55.18 & .54 & .52 & .48 & 1.28 & .09 & .23 & .32 & .18 & .08 & .02 \\
\hline SD & 11.56 & .50 & .50 & 2.52 & 6.60 & .29 & .42 & .47 & .39 & .27 & .14 \\
\hline
\end{tabular}

Note. ${ }^{*} p<.05,{ }^{* *} p<.01,{ }^{* * *} p<.001$. 


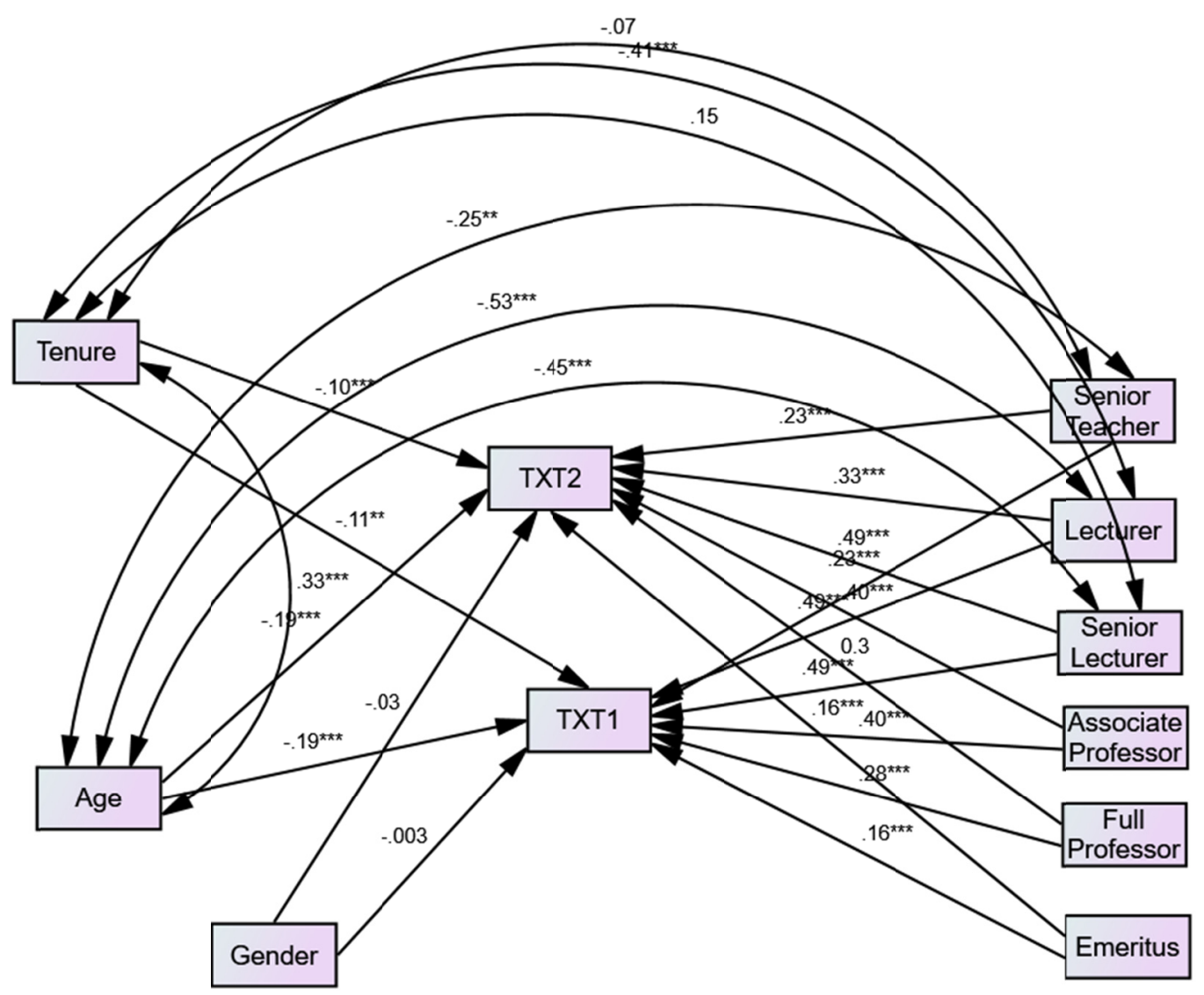

Figure 1. Model results

Note. ${ }^{* *} p<.01, * * * p<.001$.

The hypothesized model showed an excellent fit: CMIN/DF $=1.13(p>.05)$, CFI $=.99$, TLI $=.97$, RMSEA $=.051$. All hypotheses were supported. Tenure and Age negatively affect TXT1 and TXT2 (H1-H4), meaning that older and tenured people do not support an obligatory retirement age. On the other hand, all the academic ranks positively affect TXT1 and TXT2 (H5a-H51, and H6a-H61). These results suggest that there is no difference among the ranks in their approach to an obligatory retirement age. Gender had no statistical effect on TXT1 and TXT2 (H7a, H7b).

Finally, we examined whether there is any difference between the various university faculties in the approach to employment age limitation. The results suggest that working in the Faculty of Social Sciences has a positive effect on TXT2 $(\beta=.06, \mathrm{p}<.05)$ and on TXT1 $(\beta=.08, \mathrm{p}<.01)$, meaning that they support the age limitation. Working in the Faculty of Architecture had a negative effect on TXT2 $(\beta=.08, p<.01)$ and on TXT1 $(\beta=.11, p$ $<.001$ ), meaning that they do not support limitation of the employment age. Working in the Faculty of Engineering had a negative effect on TXT2 $(\beta=-.16, p<.001)$ and on TXT1 $(\beta=.2, p<.001)$, meaning they do not wish to limit the employment age. The rest of the faculties showed no statistical significance.

\section{Discussion}

The fact that personal characteristics such as age and tenure have a negative effect on the attitude towards limiting employment to retirement age (TXT1), and if there is an advantage in an obligatory retirement age to enable the absorption of new faculty members (TXT2), is underlined by the positive effect of the senior academic ranks on TXT1 and TXT2. These results imply that the perspective concerning work after retirement age is straightforward, by age and not by academic rank. The older the respondents, no matter their rank, the less they agree to limitation of the employment age.

It is evident from the research findings that the background variables that affect the views of faculty members on retirement are age and tenure-older faculty members and those with tenure show more objection to the retirement age. The significance of age and tenure is enhanced when respondents are divided by academic rank. Namely, among the various ranks, those older object to the retirement age and those younger are in favor of it. 
Hence, opinions are determined by age rather than academic rank. No effect was found for gender. With regard to the university faculties, faculty members from the Faculty of Social Services are in favor of the retirement age, those from the School of Architecture are not in favor, those from the Faculty of Engineering are not in favor, and neither are those from the Faculty of Natural Sciences and Health. As evident from the respondents' replies, young people support the retirement age due to their approach that new faculty members must be allowed to advance within the institution, therefore the young would like older faculty members to make way. Nevertheless, it is evident from the replies of the respondents that although the young support the retirement age they are certainly aware of the benefits of older faculty members and of their contribution to the academic institution.

These findings show that an optimal approach would be to let older faculty members remain active in certain areas that do not limit or bar the advancement of young faculty members. Assuming that changes are occurring in life expectancy and in quality of life in general - this is true in academia as well, also assuming that the inclusion of experienced faculty is essential and crucial and that research is an important tool in outlining the future course of academic institutions.

The reason that the young are in favor of the retirement age, as evident from the examples cited, is the approach whereby new faculty members must be allowed to advance in the institution, and therefore the older faculty should make way. Nevertheless, the respondents' replies show that despite the support for retirement age by young faculty members, they are certainly aware of the benefits of older faculty members and of their contribution to the academic institution. These findings show that an optimal approach would be to let older faculty members remain active in certain areas that do not limit or bar the advancement of young faculty members.

Accordingly, we estimate that it is possible to form a model for continued employment in academia, aimed at faculty members who have reached retirement age but continue to produce academic output and are interested in continuing to work.

In research: They can continue advising Master's and $\mathrm{PhD}$ students jointly with young faculty members who might benefit from the experience of the senior staff. They can continue publishing articles, including with their young colleagues.

In teaching: They can record their lessons, which can be used by future generations. Outstanding lecturers should be retained.

In academic administration: They can still serve in important administrative roles, participate in academic committees - and provide a different angle based on their considerable experience.

The changing life expectancy, progress, and academic excellence of productive faculty members require us to embrace a different approach, both in theory - and in practice.

\section{References}

Achdut, L., \& Litwin, H. (Eds.) (2008). The 50+ cohort - First results from SHARE-Israel: Data from the Survey of Health, Ageing, and Retirement in Israel. Bitzhon Sotziali, 76(March), 43-71. [Hebrew]

Avisar, I. (2019). There is no choice: women's retirement age must rise. Retrieved May 22, 2019, from https://www.yediot.co.il/articles/0,7340,L-5513714,00.html

Brodsky, J., Schneor, Y., \& Be'er, S. (2015). The Elderly in Israel: Statistical Abstract. Jerusalem: JDC, Brookdale Institute, Eshel. [Hebrew]

Cohen, O. (2019). Recent update: Longer life, more years on the job. Retrieved March 12, 2019, from https://www.davar1.co.il/177970/

Davidovitch, N., \& Eckhaus, E. (2018). The influence of birth country on selection of conference destination-employing natural language processing. Higher Education Studies, 8(2), 92-96. https://doi.org/10.5539/hes.v8n2p92

Davidovitch, N., \& Eckhaus, E. (2019a). Student evaluation of lecturers - what do faculty members think about the damage caused by teaching surveys? Higher Education Studies, 9(3), 12-21. https://doi.org/10.5539/hes.v9n3p12

Davidovitch, N., \& Eckhaus, E. (2019b). Teaching students to think-faculty recommendations for teaching evaluations employing automated content analysis. International Journal of Higher Education, 8(3), 83-93. https://doi.org/10.5430/ijhe.v8n3p83

Eckhaus, E. (2019a). Happiness in Fashion. In J. Kantola, S. Nazir \& T. Barath (Eds.), Advances in Human 
Factors, Business Management and Society (AHFE 2018, Advances in Intelligent Systems and Computing, Vol. 783, pp. 15-25). Cham: Springer International Publishing.

Eckhaus, E. (2019b). How to be Happy. Blog section on www.artistila.com. Retrieved from http://www.artistila.com/how-to-by-happy/

Eckhaus, E., \& Davidovitch, N. (2018a). Impact of gender and conference size on conference preferences-employing natural language processing. International Journal of Educational Methodology, 4(1), 45-52. https://doi.org/10.12973/ijem.4.1.45

Eckhaus, E., \& Davidovitch, N. (2018b). Improving academic conferences—criticism and suggestions utilizing natural language processing. European Journal of Educational Research, 7(3), 445-450. https://doi.org/10.12973/eu-jer.7.3.445

Eckhaus, E., \& Davidovitch, N. (2019). How do academic faculty members perceive the effect of teaching surveys completed by students on appointment and promotion processes at academic institutions? A case study. International Journal of Higher Education, 8(1), 171-180. https://doi.org/10.5430/ijhe.v8n1p171

Eckhaus, E., \& Sheaffer, Z. (2018a). Factors affecting willingness to contribute goods and services on social media. The Social Science Journal, 56(3), 390-400. https://doi.org/10.1016/j.soscij.2018.08.001

Eckhaus, E., \& Sheaffer, Z. (2018b). Happiness enrichment and sustainable happiness. Applied Research in Quality of Life, 14(4), 1079-1097. https://doi.org/10.1007/s11482-018-9641-0

Gorali, M. (2014). The duty of retirement is contrary to the Equal Employment Opportunity Law. Retrieved from https://www.calcalist.co.il/local/articles/0,7340,L-3623949,00.html

Hantman, S. (2012). Social work with the elderly. In N. Hovav, E. Leventhal \& Y. Katan (Eds.), Social Work in Israel (pp. 462-478). Tel Aviv: Hakibbutz Hameuchad and the Society for the Promotion of Social Work. [Hebrew]

Kimhi, A. \& Shraberman, K. (2013). Employment and Income Trends Among Older Israelis (pp. 151-184). State of the Nation Report—Society, Economy, and Policy 2013. Taub Center for Social Policy Studies in Israel. [Hebrew]

Klinov, R. (2007). Patterns of Transition into and out of and Unemployment: Israel 1995-2006. Position paper. [Hebrew]

Kreber, C. (Ed.) (2001). Scholarship revisited: Perspectives on scholarship of teaching. New Directions for Teaching and Learning, 86, 79-88. https://doi.org/10.1002/t1.18

Leitner, M., \& Leitner, S. (Eds.) (2014). Israeli Life and Leisure in the 21st Century. Urbana, IL: Sagamore. ISBN: 978-1-57167-768-6.

Mayer, E. N., Lenherr, S. M., Hanson, H. A., Jessop, T. C., \& Lowrance, W. T. (2017). Gender differences in publication productivity among academic urologists in the United States. Urology, 103, 39-46. https://doi.org/10.1016/j.urology.2016.12.064

Milgram, R. M., \& Davidovitch, N. (2010). Creative thinking and lecturer effectiveness in higher education. The International Journal of Creativity \& Problem Solving, 20(1), 7-14.

Millman, O. (2019). Ministry of Finance: Raising women's retirement age over 11 years. Retrieved June 20, 2019, from https://www.calcalist.co.il/local/articles/0,7340,L-3764737,00.html

Ministry of Finance. (2015). Report of the Supervisor in Charge of the Capital Market, Insurance, and Savings, for 2014. [Hebrew]

Molina-Azorin, J. F. (2016). Mixed methods research: An opportunity to improve our studies and our research skills. European Journal of Management and Business Economics, 25, 37-38. https://doi.org/10.1016/j.redeen.2016.05.001

Narhari, S. A., \& Shedge, R. (2017). Text categorization of Marathi documents using modified LINGO. Paper presented at the 2017 International Conference on Advances in Computing, Communication and Control (ICAC3). https://doi.org/10.1109/ICAC3.2017.8318771

Paltiel, A., Spolker, M., Konilko, A., \& Maldondo, M. (2011). Long-Term Population Forecasts 2009-2059. Jerusalem: Central Bureau of Statistics. [Hebrew]

Richert-Kaźmierska, A. (2014). Employees 55+-valuable resource in SMEs. Social Sciences, 85(3), 49-57. https://doi.org/10.5755/j01.ss.85.3.8413 
Schreiber, J. B., Nora, A., Stage, F. K., Barlow, E. A., \& King, J. (2006). Reporting structural equation modeling and confirmatory factor analysis results: A review. The Journal of Educational Research, 99(6), 323-338. https://doi.org/10.3200/JOER.99.6.323-338

Stegers - Jager, K. M., Cohen - Schotanus, J., \& Themmen, A. P. (2012). Motivation, learning strategies, participation and medical school performance. Medical Education, 46(7), 678-688. https://doi.org/10.1111/j.1365-2923.2012.04284.x

Tur-Sinai, A. (2016). Employment and retirement among senior citizens in Israel: Main economic features. Jerusalem: Information Center for Research on Aging in the Israeli Population. Hebrew University. [Hebrew]

Weissberg, H. (2012). Academics against the Retirement Age Law: "Leaves the decision to the employer". Retrieved August 23, 2012, from https://www.themarker.com/career/1.1807705

\section{Copyrights}

Copyright for this article is retained by the author, with first publication rights granted to the journal.

This is an open-access article distributed under the terms and conditions of the Creative Commons Attribution license (http://creativecommons.org/licenses/by/4.0/). 